Thailand. Association for the Conservation of Wildlife, Bangkok.

Pocock, R.I. 1932. The marbled cat (Pardofelis marmorata) and some other Oriental species, with the definition of a new genus of the Felidae. Proceedings of the Zoological Society of London, 132, 741-766.

US Fish and Wildlife. Service. 1991. Endangered and Threatened Wildlife and Plants. US Government
Printing Office, Washington, DC, 37 pp.

Weigel, I. 1961. Das Fellmuster der wildlebenden Katzenarten und der Hauskatze in Vergleichender und Stammesgeschichtlicher Hinsicht. Säugetierkundliche Mitteilungen, 9, 1-120.

Wozencraft. W.C. 1993. Order Carnivora. In Mammal Species of the World (eds D. E. Wilson and D. M. Reeder), 2nd edn., pp. 279-348. Smithsonian Institution Press, Washington DC.

\title{
The decline of the wild water buffalo in north-east India
}

The Asiatic wild buffalo Bubalus bubalis was widely distributed in the river systems of south and South East Asia, but habitat destruction, hunting and interbreeding with domestic water buffalo have resulted in only relict wild populations remaining. Unless protection measures are intensified, the species could disappear in India within a few decades.

\section{Introduction and methods}

The bulk of the wild buffalo remaining in India are found in or near the Brahmaputra Valley in the provinces of Assam, Arunachal Pradesh and Meghalaya. The only other area having wild water buffalo is the Indravati National Park and locally elsewhere in the Indravati Valley west of the Madhya Pradesh-Orissa border. It was found over large areas in the Brahmaputra Valley, but it is now restricted to a few localities. Some information on the distribution of the species is given in Gee (1964), Sheshadri (1969) and Grewel et al. (1987, p. 98), but detailed information on distribution and status is lacking. From 1985 to 1993 I was able to carry out field surveys in various parts of north-east India to determine the current distribution and status of the wild buffalo, as part of broader surveys concentrating on primates. As well as travelling widely in Assam, I visited parts of Arunachal Pradesh, Nagaland, Manipur, Mizoram and Meghalaya. In most cases I was able to observe the animals directly, but in

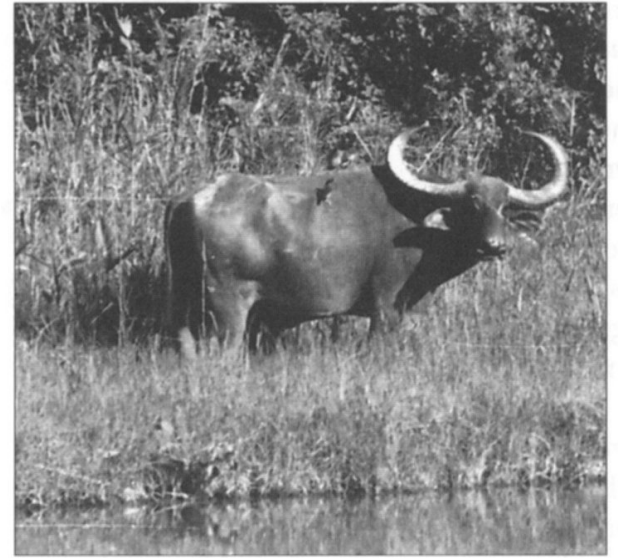

A wild bull buffalo in Dibru-Saikhowa Sanctuary, Assam (A. Choudhury).

some cases I had to rely on interviews with local people and forest officials.

\section{Results}

The current distribution and estimated populations are given in Table 1 and Figure 1. Comments on the data are given below.

Water buffalo favour low-lying wet areas with tall elephant grass, including beels (oxbow lakes and other depressions left by changes in the course of a river), river banks, and chaporis (sandy islets situated between branches of a river in a braided river system). In some instances the populations extend into woodland. The buffalo were active in the daytime only in areas where they are well protect- 
ed; where there was substantial human disturbance they were active mainly at night.

Currently buffalo occupy only about 1500 $\mathrm{sq} \mathrm{km}$ in Assam, $200 \mathrm{sq} \mathrm{km}$ in Arunachal Pradesh, and something under $200 \mathrm{sq} \mathrm{km}$ in Meghalaya. Forest Department estimates suggest a total of 2300 in Kaziranga and Manas National Parks combined, and my estimates based on interviews with local people and Forest Department staff together with my own observations total about $700-900$ in the remainder of Assam, 150 in Arunachal

Table 1. Distribution and population estimates of wild water buffalo in Assam, Arunachal Pradesh and Meghalaya

\begin{tabular}{|c|c|c|c|}
\hline \multicolumn{2}{|c|}{ Area/locality } & Location & $\begin{array}{l}\text { Estimated } \\
\text { population }\end{array}$ \\
\hline \multicolumn{4}{|c|}{ Assam } \\
\hline \multirow[t]{2}{*}{1} & Manas NP & Barpeta, Bongaigaon & \\
\hline & & Kokrajhar and Nalbari & 1200 \\
\hline $2 a$ & $\begin{array}{l}\text { Kaziranga NP and adjoining } \\
\text { areas including Kukurakata RF } \\
\text { and Deochur }\end{array}$ & Golaghat, Nagaon and Sonitpur & 1100 \\
\hline $2 b$ & Panpur RF & Sonitpur & Visitors from \\
\hline $2 c$ & Khatonibari SCA & Sonitpur & Kaziranga \\
\hline $3 a$ & Laokhowa WLS & Nagaon & \\
\hline $3 b$ & Burhachapori RF & Sonitpur & 200 \\
\hline $3 c$ & $\begin{array}{l}\text { Rone Tapu (Baghe Tapu) } \\
\text { chapori }\end{array}$ & Sonitpur & \\
\hline 4 & Patradisa RF & Karbi Anglong & 3 (stray group) \\
\hline 5 & Dhansiri RF & Karbi Anglong & Small \\
\hline $6 a$ & Kadam RF & Lakhimpur & \\
\hline $6 b$ & Borchapori & Lakhimpur & $100-150$ \\
\hline $6 c$ & Kaopak chapori & Lakhimpur & \\
\hline $6 \mathrm{~d}$ & Dulung and Kakoi RFs & Lakhimpur & $\begin{array}{l}\text { Wanderers from } \\
\text { Kadam during high flood }\end{array}$ \\
\hline 7 & Dhakuakhana (Borkalia) & Lakhimpur & 5 \\
\hline $8 a$ & Jamjing RF & Dhemaji ) & $150-200$ \\
\hline $8 b$ & Sengajan RF & Dhemaji $\}$ & \\
\hline $9 a$ & Dibru-Saikhowa WLS & Tinsukia, Dibrugarh and Dhemaji & \\
\hline $9 b$ & $\begin{array}{l}\text { Koplong chapori (now a part } \\
\text { of Dibru-Saikhowa) }\end{array}$ & Dhemaji & 250 \\
\hline $9 c$ & Poba RF & Dhemaji & \\
\hline $9 \mathrm{~d}$ & Kobo chapori & Dhemaji & \\
\hline $9 e$ & Amarpur (Dibang) chapori & Tinsukia & \\
\hline 10 & Doom dooma RF & Tinsukia & $8-9$ \\
\hline 11 & Kollolua & Dibrugarh & $13-15$ \\
\hline \multicolumn{4}{|c|}{ Arunachal Pradesh } \\
\hline 12 & D'Ering WLS & East Siang & $\begin{array}{l}100 \text { (approx., habitat contiguous } \\
\text { with 9d) }\end{array}$ \\
\hline 13 & Dibang RF & Dibang Valley & Small and scattered \\
\hline \multicolumn{4}{|c|}{ Meghalaya } \\
\hline 14 & Balphakram NP & South Garo Hills & Small \\
\hline
\end{tabular}

NP, National Park; WLS ,Wildlife Sanctuary; RF, Reserved Forest; SCA, Soil Conservation Area. Bracketing indicates reserves/areas are contiguous. The wild buffalo became extinct in Pabha RF (Lakhimpur district) and Gali RF (Dhemaji district) during the 1970s. There are no captive populations in any zoos. 


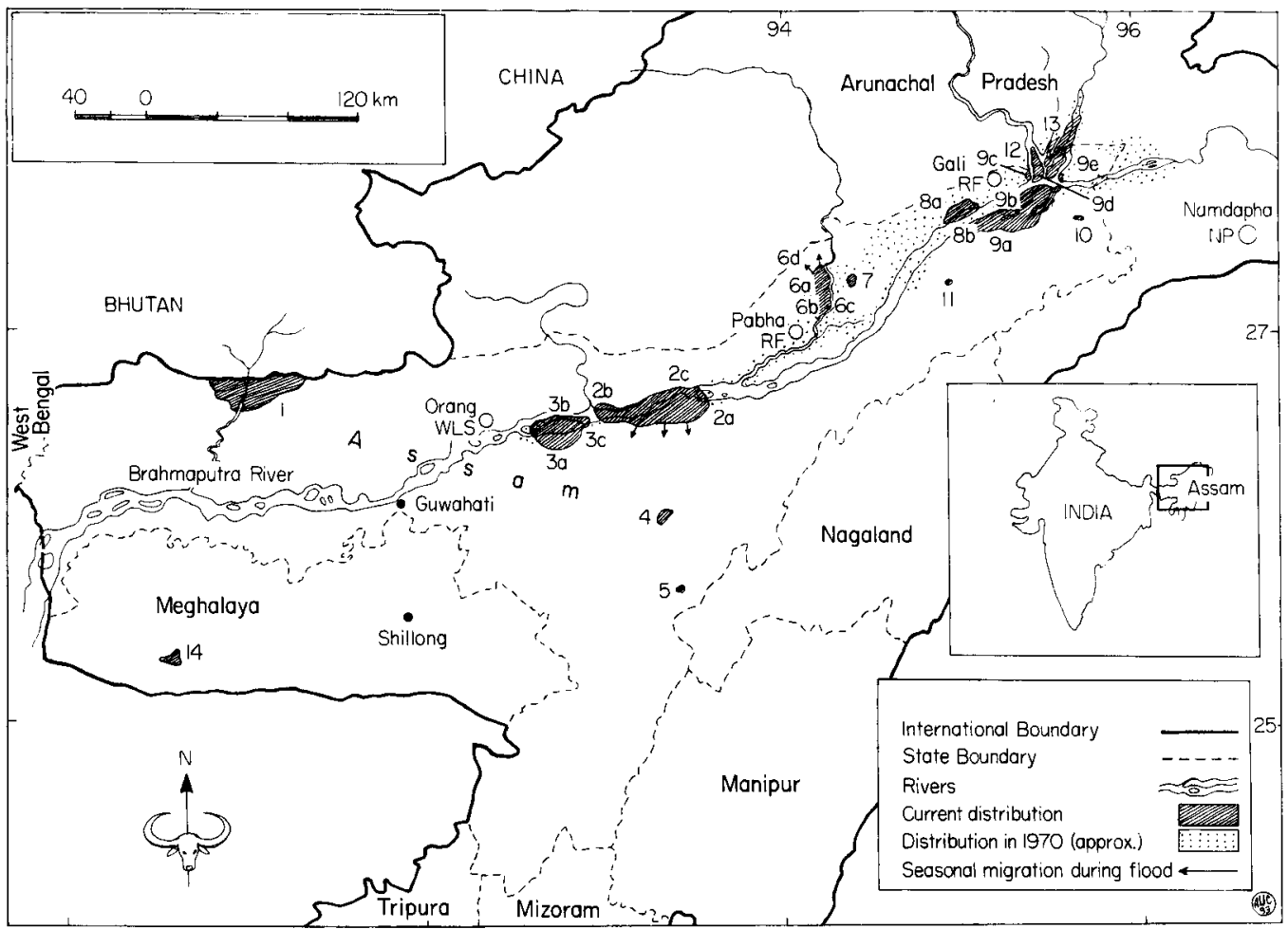

Figure 1. Map showing the distribution of the wild buffalo in Assam and adjacent states of India.

Pradesh and an unknown small number in Meghalaya: in all totalling perhaps $3300-3500$ individuals.

\section{Causes of decline in numbers}

\section{Destruction of habitat}

Except in Kaziranga National Park, D'Ering Wildlife Sanctuary, Dibru-Saikhowa Wildlife Sanctuary, Balphakram National Park and the core area of Manas National Park, water buffalo habitat is vanishing. Hundreds of hectares of elephant-grass jungle are cleared every year for cultivation of crops, such as rice and mustard. Because the areas concerned have alluvial soils and are suitable for winter crops, it is impossible to prevent clearance except in closely protected reserves. In the $107-\mathrm{sq}-\mathrm{km}$ Gali Reserved Forest in Dhemaji district, for example, there is no buffalo habitat left.

\section{Hunting}

The wild water buffalo is listed as endangered in Schedule 1 of the Indian Wild Life (Protection) Act 1972, which prohibits both its killing and its capture. However, it is killed frequently for food with guns or spears in the Lakhimpur and Dhemaji districts by the Mising (plains Miri) tribal people, who live in the upper Brahmaputra Valley. This is mainly done when the rivers are in flood and the buffalo take refuge on small areas of raised ground. In the East Siang and Dibang Valley districts of Arunachal Pradesh, the Adi (Abor) tribal people, who are ethnically very close to Mising, kill wild buffalo for food. There is also limited hunting elsewhere.

\section{Disease transmission and grazing by domestic cattle and other livestock}

Rinderpest is a serious threat. It killed at least 150 buffaloes in 1981 in Kaziranga National 
Park, and in the mid-1970s more than 100 in the Dhakuakhana area. This and other bovine diseases are readily transmitted by domestic livestock, which can also deplete the food supply by overgrazing. Domestic water buffalo offer a further threat to wild populations through the readiness with which the two interbreed and the fact that they can outnumber the wild herds in smaller areas. In and around the Kadam Reserved Forest some 300-400 domestic buffaloes graze throughout the year and their number can reach 6000 during times of flood. About 200 domestic buffaloes and 1600 cattle graze in the $D^{\prime}$ Ering Wildlife Sanctuary. There is a similar situation in the other reserves except Kaziranga and Manas National Parks, where the core areas are free of domestic livestock.

\section{Recommendations for conservation}

1. Create more wildlife sanctuaries. I suggest the areas listed below should be declared sanctuaries without delay.

* Burhachapori Reserved Forest together with Baghe (Rone) Tapu chapori and Kochmora chapori totalling $70 \mathrm{sq} \mathrm{km}$.

* Kadam Reserved Forest together with Borchapori and Kaopak chapori totalling 50 $\mathrm{sq} \mathrm{km}$.

* Borkalia, near Dhakuakhana, about $5 \mathrm{sq} \mathrm{km}$. * Jamjing and Sengajan Reserved Forests, totalling $100 \mathrm{sq} \mathrm{km}$.

* Kobo chapori together with Poba Reserved Forest, totalling about $200 \mathrm{sq} \mathrm{km}$.

* Part of Dibang Reserved Forest together with Sirkee Proposed Reserved Forest, totalling about $150 \mathrm{sq} \mathrm{km}$.

2. Provide effective management of existing wildlife sanctuaries. Dibru-Saikhowa, Laokhowa and D'Ering Wildlife Sanctuaries should be protected and managed in the same way as
Kaziranga and Manas National Parks, including prevention of grazing of livestock in the core areas and minimizing grazing in the peripheral areas.

3. Identify core and peripheral zones in national parks and wildlife reserves. The Indian Wild Life (Protection) Act 1972 should be amended to provide for core areas and buffer zones to be demarcated in all national parks and wildlife sanctuaries, with ploughing and the grazing of livestock being prohibited in the former and allowed on a limited scale in the latter. It is impracticable to attempt to prevent grazing of livestock and arable cultivation throughout the area suitable as habitat for the buffalo.

Unless action on the lines suggested above is taken soon, wild buffalo may disappear within 20 years except in the national parks.

Anwaruddin Choudhury, Near Gate No. 1 of Nehru Stadium, Islampur Road, Guwahati 781

007, Assam, India

Acknowledgments

I gratefully acknowledge the help of forest officials and local villagers, including Padma Dihingia and Lankeswar Pegu of Dhakuakhana, R. Bhattacharjee, N. Sharma and Paniram of Dibru-Saikhowa, Golok Sharma of Burhachapori-Laokhowa, Leto Mili of Dibang Valley, S. Rongphar of Karbi Anglong, and Nur Husain. I also thank the Science, Technology and Environment Council of Assam for financial assistance in carrying out fieldwork since September 1990.

\section{References}

Gee, E.P. 1964. The Wildlife of India. Collins, London. Grewel, B., Israel, S. and Sinclair, T. (eds). 1987. Indian Wildlife. APA Productions (HK) Ltd, Hong Kong.

Sheshadri, B.K. 1969. The Twilight of India's Wildlife. John Baker, London. 